УДК 330.5:338.124.4

Талах B.I., к.е.н., доцент

Талах Т.А., к.е.н., доцент

Луцький національний технічний університет

\title{
МОНІТОРИНГ ФІНАНСОВОЇ НЕСТАБІЛЬНОСТІ НАЦІОНАЛЬНОЇ ЕКОНОМІКИ В УМОВАХ ЕКОНОМІКО-ПОЛІТИЧНИХ ТРАНСФОРМАЦІЙ
}

Діагностика фінансової нестабільності є важливим елементом антикризового управління, суттєвим чинником його ефективності. Процес діагностики неможливий без визначення системи критеріїв, здатних адекватно відобразити специфіку конкретного об'єкта з урахуванням найбільш суттєвих чинників впливу на нього в той чи інший період часу.

В публікації узагальнено наявні в світовій практиці та Україні напрацювання щодо методичних підходів до діагностики фінансової нестабільності національної економіки в цілому, та визначення індикаторів фінансових криз, як невід’ємної складової зародження та розвитку сучасних економічних криз, зокрема. Окреслений сучасний стан, тенденції становлення та особливості їх застосування для виявлення та запобігання кризових процесів в Україні.

Особлива увага приділена порівняльному аналізу методів оцінки нестійкості економіки та можливостей їх використання при формуванні методичного підходу діагностики кризовості національної економіки. Саме на підставі таких даних можна відкоригувати економічну, політичну та соціальну концепції управління, їх стратегію і тактику.

Ключові слова: кризові процеси розвитку національної економіки, діагностика кризи, оцінка кризових процесів, індикатори фінансових криз.

Talakh V., Talakh T.

\section{MONITORING OF FINANCIAL INSTABILITY OF NATIONAL ECONOMY IN CONDITIONS OF ECONOMIC AND POLITICAL TRANSFORMATION}

Diagnosis of financial instability is an important element of crisis management, a significant factor in its effectiveness. The process of diagnosis is impossible without defining a system of criteria that can adequately reflect the specificity of a particular object, taking into account the most significant factors affecting it at one time or another.

The publication summarizes the experience in the world and Ukraine on methodological approaches to the diagnosis of financial instability of the national economy as a whole, and identifying indicators of financial crises as an integral component of the emergence and development of modern economic crises, in particular. The current state, tendencies of formation and peculiarities of their application for detection and prevention of crisis processes in Ukraine are outlined.

Particular attention is paid to the comparative analysis of methods of assessing the instability of the economy and the possibilities of their use in forming a methodological approach for the diagnosis of crisis of the national economy. It is on the basis of such data that the economic, political and social concepts of governance, their strategy and tactics can be adjusted.

Keywords: crisis processes of development of national economy, crisis diagnostics, assessment of crisis processes, indicators of financial crises.

Талах В.И., Талах Т.А.

\section{МОНИТОРИНГ ФИНАНСОВОЙ НЕСТАБИЛЬНОСТИ НАЦИОНАЛЬНОЙ ЭКОНОМИКИ В УСЛОВИЯХ ЭКОНОМИКО-ПОЛИТИЧЕСКОЙ ТРАНСФОРМАЦИИ}

Диагностика финансовой нестабильности является важным элементом антикризисного управления, существенным фактором его эффективности. Процесс диагностики невозможен без определения системы критериев, способных адекватно отразить специфику конкретного объекта с учетом наиболее существенных факторов влияния на него в тот или иной период времени.

В публикации обобщены имеющиеся в мировой практике и Украине наработки по методическим подходам к диагностике финансовой нестабильности национальной экономики в целом, и определения индикаторов финансовых кризисов, как неотъемлемой составляющей зарождения и развития современных 
экономических кризисов, в частности. Охарактеризованы современное состояние, тенденции становления и особенности их применения для выявления и предотвращения кризисных процессов в Украине.

Особое внимание уделено сравнительному анализу методов оценки неустойчивости экономики и возможностей их использования при формировании методического подхода диагностики кризиса национальной экономики. На основании таких данных можно откорректировать экономическую, политическую и социальную концепции управления, их стратегию и тактику.

Ключевые слова: кризисные процессы развития национальной экономики, диагностика кризиса, оценка кризисных процессов, индикаторы финансовых кризисов.

Постановка проблеми у загальному вигляді i iї зв'язок 3 важливими науковими та практичними завданнями. Вимірювання рівня та визначення стадії розвитку кризи в якій знаходиться національна економіка $є$ важливим при формуванні пріоритетів державної політики, адже без врахування поточного стану соціальноекономічного розвитку держави неможливо здійснити підбір ефективних інструментів стратегічного та оперативного управління нею.

В сучасних умовах основний акцент у формуванні економічної політики, щодо пошуку збалансованої моделі сталого розвитку територій та розробки ефективної концепції їх розвитку, перенесено на діагностику фінансової стабільності національної економіки.

В контексті сказаного, необхідно особливу увагу зосередити на передчасному виявленні та діагностуванні видів економічної діяльності, найбільш вразливих до кризових процесів. Адже на підставі таких даних можна відкоригувати економічну, політичну та соціальну концепції управління, їх стратегію i тактику. Діагностика кризи є важливим елементом антикризового управління, суттєвим чинником його ефективності. Процес діагностики неможливий без визначення системи критеріїв, здатних адекватно відобразити специфіку конкретного об'єкта з урахуванням найбільш суттєвих чинників впливу на нього в той чи інший період часу.

Аналіз останніх досліджень, у яких започатковано вирішення проблеми. Прояви циклічності у розвитку економіки як в світовому, так і національному масштабі змушує науковців розробляти різні методи виміру даного явища. Методичні аспекти оцінки кризових процесів розвитку економіки розглянуті у працях зарубіжних вчених: Дж. Азіза, А. Бартелемі, А. Берга, Е. Боренштейна, Ч. Віплоша, Р. Гліка, С.М. Дробишевського, Б. Ейхенгріна, Дж. Камінскі, Дж.Д. Капріо, Ф. Карамацци, Д. Клінгебіель, А.В. Комкової А. Коршуна, Д. Крука, С. Лізондо, Дж.М. МілессіФеретті, Р. Морено, К.А. Патілло, Г.І. Плешанова, К. Рейнхарт, А.К. Роуза, Л. Річчі, Р. Сальгадо, С.Г. Синельникова-Мурильова, I.В. Труніна, Дж.А. Френкеля, А.Д. Юдіна, О.В. Шкребели та ін., вітчизняних науковців: О. Сидоренко, О. Барановського та ін.

Різноманіття методик підтверджує відсутність єдиного підходу до кількісної та якісної оцінки кризових процесів розвитку національної економіки. Особливості розвитку кожної країни та іiі територій, складність отримання та опрацювання статистичних даних вимагають використання різних методів задля достовірного, аутентичного, точного отримання результатів про масштаби кризових процесів в національній економіки. Негативні наслідки світової кризи призвели до загострення соціально-економічних проблем, які стали актуальними не лише для інших країн світу, a i для України. Не дивлячись на різноманіття методик кількісної та якісної оцінки кризових процесів всі автори єдині у думці, що основним засобом виживання вітчизняних товаровиробників у таких умовах $\epsilon$ розроблення та впровадження ефективного механізму антикризового управління, важливе місце у якому займає діагностика поточного стану справ. В умовах нестабільного зовнішнього середовища перед мезо- та макроекономічними системами постає завдання проведення постійного моніторингу діяльності, виявлення та оцінки можливих напрямків розвитку. Вітчизняна методологія оцінки кризового стану не повністю відповідає сучасним вимогам господарювання, а зарубіжний досвід не належною мірою адаптований до українських законів й основних положень бухгалтерського обліку та аудиту. Це зумовлює потребу в 
розробленні вітчизняної моделі аналізу схильності національної економіки до кризи, яка б враховувала галузеву специфіку, стадії розвитку кризи, поточні результати діяльності, давала точну та об'єктивну оцінку кризового стану, на основі розрахунку ключових індикаторів і показників.

Цілі статті. Проведення порівняльного аналізу методів оцінки нестійкості економіки та можливостей їх використання при формуванні методичного підходу діагностики кризовості національної економіки. Узагальнення наявних у світовій практиці та в Україні напрацювань щодо методичних підходів до діагностики фінансової нестабільності національної економіки, та визначення індикаторів фінансових криз, як невід'ємної складової зародження та розвитку сучасних економічних криз, зокрема.

Виклад основного матеріалу дослідження 3 повним обгрунтуванням отриманих наукових результатів. Моніторинг фінансової нестабільності країн здійснювали низка вчених, зокрема, Дробишевський С.М., Синельников-Мурильов С.Г., Трунін П.В., Юдін А.Д. та Шкребела О.В., які для вибору найкращих індикаторів виокремили наступні групи підходів [1, С. 5]:

1. Якісний аналіз - підхід, який передбачає графічне зіставлення динаміки фундаментальних економічних показників в період перед фінансовою кризою i в спокійному стані і розрахунок деяких статистичних індикаторів, що характеризують динаміку часових рядів індикаторів-передвісників фінансової нестабільності.

2. Економетричне моделювання - підхід, при якому будуються регресійні моделі, що дозволяють оцінити взаємозв'язок показників з ймовірністю настання фінансової кризи в майбутньому.

3. Непараметричні оцінки - підхід, при якому розробляються різні числові характеристики, що дозволяють завчасно виявляти вразливість економіки країни до фінансової кризи: побудова граничних значень індикаторів-передвісників фінансової кризи на основі різних критеріїв, а також розробка зведених індексів фінансової стабільності.

Використання зазначеного підходу доцільне при оцінці кризовості національної економіки 3 проведенням якісного аналізу, економетричного моделювання та непараметричних оцінок. Однак, необхідно детально оцінити потенціал національної економіки щодо антикризової стійкості та виокремити порогові значення показників, що свідчитимуть про стани стабілізації, зростання, спаду, кризи.

У працях Гліка Р. i Морено Р. [2] досліджувались кризи в країнах Східної Азії та Латинської Америки в період 1972-1997 pр. Авторами пропонувався аналіз динаміки наступних показників: 1) індикатори грошового ринку (номінальна і реальна грошова маса M2; грошовий мультиплікатор; відношення грошової маси М2 до золотовалютних резервів; внутрішній кредит у реальному вираженні); 2) показники конкурентоспроможності і торгівлі (відхилення реального ефективного обмінного курсу від тренду (тобто залишки регресії реального ефективного обмінного курсу на константу, тренд, експорт, імпорт та відношення чистого експорту до сукупного експорту); динаміка експорту; сальдо торгового балансу).

Здійснений ними графічний аналіз показав, що зростання грошової маси в реальному вираженні та внутрішнього кредиту в реальному вираженні сповільнюється перед кризою, що свідчить про зниження економічної активності. Вважаємо, що такий результат дослідження суперечить іншим аналогічним науковим працям, в яких про наближення кризи свідчить різке збільшення грошової пропозиції. Грошовий мультиплікатор перед кризою підвищується, що стає помітно приблизно за місяць до їі початку. Крім того, автори виявили тенденцію зниження золотовалютних резервів перед настанням кризи, що потребує додаткових досліджень щодо можливостей застосування досліджень Гліка Р. і Морено Р. при оцінці кризовості національної економіки.

Комкова А.В. та Плешанов Г.І. вважають, що економічні індикатори за своєю природою (послідовністю змін в макроекономічній системі) можна розділити на три великі групи [3, С. 20-21]: 
1. Випереджальні індикатори. Складний індекс випереджальних індикаторів складається 311 рядів вимірювань коригування маржинальної зайнятості; капітальних вкладень; інвестицій у товарно-матеріальні запаси; прибутковості; грошових і фінансових потоків.

2. Індикатори збігу. Складний індекс індикаторів збігу складається 34 рядів, в яких враховуються зайнятість, особистий дохід, промислове виробництво і реалізація продукції. Максимально високі і максимально низькі значення цих рядів в основному збігалися 3 загальними тенденціями в економіці.

3. Запізнілі індикатори. Складний індекс запізнілих індикаторів складається з 7 рядів, в яких враховуються зайнятість, товарно-матеріальні запаси, прибутковість, умови фінансового ринку. Максимально високі і максимально низькі значення цих рядів в основному мали місце пізніше, ніж піки і спади відповідного циклу ділової активності, тому їх пов'язують 3 деякою інерцією або адаптивними очікуваннями. Кожен показник може бути зарахований до тієї чи іншої групи, однак ступінь кореляції різних показників по відношенню до етапу розвитку економічного циклу може бути різною [4, С. 20].

Застосування випереджаючих індикаторів, індикаторів збігу та запізнілих індикаторів $\epsilon$ доцільним при формування методичного підходу до оцінки кризовості національної економіки. Адже відомо, що несвоєчасність та невідповідність заходів економічної політики держави може істотно збільшити глибину спаду і «затримати» вихід економіки 3 кризи. Зведені випереджаючі індекси довели свою ефективність при підборі методів діагностики та прогнозування фаз економічного циклу та прийнятті рішень антикризового управління національною економікою.

Сидоренко О.Ю. у своїх дослідженнях пропонує формувати систему індикаторівпередвісників як зваженої комбінації поданих вище підходів. Основою іiї підходу є зведення країн (стану їх економіки за певний період часу) в окремі групи за допомогою кластерного аналізу. Окрім кількісних змінних, автор пропонує використовувати також і якісні у формі чисельних нормалізованих значень - наприклад, зміна, що вимірюється за експоненціальним законом від 0 до 1 , де 0 присвоюється країні, яка мала кризу в попередній період, i 1, де криза відсутня [5, С. 6-7]. Так, Сидоренко О.Ю. запропоновані такі групи індикаторів-передвісників: 1) показники, що характеризують стан реальної економіки; 2) показники зовнішнього сектору; 3) показники грошово-кредитного і валютного ринків.

Використання системи індикаторів фінансової стабільності на основі кластеризації країн дозволяє адекватно оцінити стан економіки країни у порівнянні з іншими країнами за умови належного підбору індикаторів.

Апробація методик моніторингу випереджаючих індикаторів стійкості національної економіки, розроблених вченими провідних науково-дослідних установ та експертноконсалтинговими агентствами, не дозволяе спрогнозувати настання фінансових криз. Так, дослідники інституту «Центр розвитку ГУ-ВШЕ» вважають, що тільки 5 індикаторів для визначення поворотних точок в економіці можуть бути використані для безпосереднього порівняння один 3 одним: індекс менеджерів 3 постачання (PMI) за Markit; зведені випереджаючі індекси (CLI) Центру розвитку або ОЕСР; індекс промислової довіри (ICI) Вищої школи економіки; індекс промислового оптимізму (IOI) Інституту Е.Т. Гайдара [6].

У загальносвітовому масштабі найвідомішим і найбільш досліджуваним еквівалентом $\epsilon$ індекс випереджаючих показників (CLI), що публікується OECD. На основі економічної інформації, що надходить з країн-членів OECD, розраховується індекс CLI 3 метою прогнозування майбутнього промислового виробництва в окремих державах і регіонах OECD. Протягом багатьох років індекс CLI зарекомендував себе в якості ефективної системи раннього оповіщення, здатної передбачати піки і провали кривої економічної активності приблизно за 9 місяців до настання кризи. В якості компонентів складеного індексу використовуються фінансові показники. При визначенні загального складеного індексу випереджаючих показників за даними OECD використовується близько 160 компонентів. До числа найбільш поширених національних компонентів, що використовуються OECD в розрахунку CLI, входять курси акцій, дозвіл на будівництво, дані 
грошової системи та замовлення на виробництво. На кожну країну припадає від 5 до 11 показників. Потім для кожної з країн, а також для кожного з регіонів підраховується свій щомісячний індекс. Якщо протягом 3 послідовних місяців спостерігається стабільно негативне або стабільно позитивне значення піврічного рівня змін, то шанси, що через 0,51 рік економіка країни досягне своєї нижчої чи вищої точки розвитку, дуже великі.

Крук Д. та Коршун А. виділяють чотири групи економічних змінних, від яких можна очікувати проявів випереджаючого впливу відносно економічного циклу (OECD) [7, C. 7 8]:

1. Змінні, що характеризують ранні стадії виробництва в економіці (наприклад, до цієї групи можна віднести нові замовлення на поставку в окремих галузях економіки, замовлення на кінцеву продукцію деяких галузей, придбання нової нерухомості, придбання товарів тривалого користування та ін.).

2. Змінні, що демонструють швидку реакцію на мінливу економічну кон'юнктуру (до цієї групи можуть входити, наприклад, показники, що характеризують динаміку ринку праці: створення нових робочих місць, кількість прийнятих на роботу і звільнених, кількість відпрацьованих годин, обсяг втрат робочого часу, динаміка прибутку, запасів сировини, матеріалів, а також готової продукції).

3. Змінні, що чутливі до очікувань економічних агентів (найбільш популярними показниками цієї групи $є$ результати опитувань населення, бізнесу та інших груп економічних агентів щодо їх економічної активності і очікувань, ціни активів (біржові індекси), а також ціни на сировинні товари). Часто на основі такого роду опитувань складаються спеціальні індекси бізнес-клімату, споживчих настроїв тощо, які можуть виступати в якості компонентів зведеного індексу випереджальних індикаторів.

4. Змінні, що першими відчувають вплив змінної фази економічного циклу (до цієї групи переважно належать показники, пов'язані з монетарною середовищем і зовнішнім сектором економік: величина грошової пропозиції, попиту на окремі грошові агрегати, процентні ставки, обсяг наданих кредитів, умови торгівлі та ін.).

Висновки. Останні краш-тести випереджальних індексів показали, що більшість 3 них не зможуть вказати на симптоми нової фінансової кризи через плутанину методології та неперіодичності виходу з кризових ситуацій. Це потребує формування нових методичних підходів до діагностики кризовості національної економіки.

Використання зведеного випереджаючого індексу (CLI) OECP вважаємо за доцільне при формуванні методичного підходу до оцінки кризовості національної економіки, однак необхідно здійснювати і розрахунок потенціалу національної економіки щодо стійкості до виникнення кризи та розрахунок реальних та запізнілих індикаторів.

Розрахунок індексу промислової довіри та індексу промислового оптимізму доцільно використовувати як один із показників оцінки потенціалу антикризової стійкості національної економіки 3 метою визначення економічних інтересів попиту споживачів та пропозиції виробників.

\section{Список бібліографічного опису:}

1.Дробышевский С. М., Синельников С. Г., Трунин П. В., Юдин А. Д., Шкребела Е. В. Мониторинг финансовой нестабильности в развивающихся экономиках (на примере России) под руков. С. М. Дробышевского. Москва: Ин-тут економи переходного типа, 2007. 89c.

2.Glick R., Moreno R. Money and Credit, Competitiveness, and Currency Crises in Asia and Latin America Economisch Institut voor het Midden en Kleinbedrijf, 1999.

3.Комкова А. В., Плешанов Г. И. Тенденции формирования Российской системы базисных социально-экономических индикаторов Экономическая політика. Серия «Экономика и право». 2012. №2 (8). С. 19-23.

4.Комкова А. В., Плешанов Г. И. Тенденции формирования Российской системы базисных социально-экономических индикаторов Экономическая політика. Серия «Экономика и право». 2012. №2 (8). С. 19-23.

5.Сидоренко О. Ю. Окремі підходи до відбору та використання індикаторів-передвісників фінансової нестабільності Вісник Університету банківської справи Національного банку України. 2011. №3 (12). С. 6-10.

6.Литвинова А. Большинство моделей не могут предсказать потрясения в российской экономике. Газета-онлайн «РБК daily» // [Электронный ресурc]. Режим доступа: http://www.rbcdaily.ru/politics/562949979211466.

7. Крук Д., Коршун А. Экономический цикл и опережающие индикаторы: методологические подходы и возможности использования в Беларуси Минск : Исследовательский центр ИПМ, 2010. 35 с.

\section{References:}

1. Drobyshevsky S., Sinelnikov S., Trunin P., Yudin A., Shkrebel E. (2007) Monitoring finansovoj nestabilnosti v razvivayushihsya ekonomikah [Monitoring financial instability in emerging economies]. Moscow: In-tut economy of transition type, 89. [in Russian]. 
2. Glick R., Moreno R. (1999) Money and Credit, Competitiveness, and Currency Crises in Asia and Latin America Economisch Institut voor het Midden en Kleinbedriff.

3. Komkova A., Pleshanov G. (2012) Tendencii formirovaniya Rossijskoj sistemy bazisnyh socialno-ekonomicheskih indikatorov [Trends in the formation of the Russian system of basic socio-economic indicators]. Ekonomicheskaya politika. Seriya «Ekonomika i pravo»- Economic policy. Series "Economics and Law"., 2 (8) 19-23. [in Russian].

4. Komkova A., Pleshanov G. (2012) Tendencii formirovaniya Rossijskoj sistemy bazisnyh socialno-ekonomicheskih indikatorov [Trends in the formation of the Russian system of basic socio-economic indicators]. Ekonomicheskaya politika. Seriya «Ekonomika i pravo»- Economic policy. Series "Economics and Law"., 2 (8) 19-23. [in Russian].

5. Sydorenko O. (2011) Okremi pidhodi do vidboru ta vikoristannya indikatoriv-peredvisnikiv finansovoyi nestabilnosti [Selected approaches to the selection and use of precursors to financial instability]. Visnik Universitetu bankivskoyi spravi Nacionalnogo banku Ukrayini - Bulletin of the National Bank of Ukraine's Banking University., 3 (12) 6-10. [in Ukrainian]. 6. Litvinova A. Most models cannot predict shocks in the Russian economy. «RBK daily" URL: http:// www.rbcdaily.ru/politics/562949979211466

7. Kruk D., Korshun A. (2010) Ekonomicheskij cikl i operezhayushie indikatory: metodologicheskie podhody i vozmozhnosti ispolzovaniya $v$ Belarusi Minsk [Economic cycle and leading indicators: methodological approaches and possibilities of use in Belarus Minsk]. Issledovatelskij centr IPM - IPM Research Center., 35. [in Russian]

Рецензент д.е.н., професор Вахович I.M. 